\title{
Performance Measurement of Diagnostic X Ray System
}

\author{
Ingyu You,**, Cheonghwan Lim*, Sangho Lee**, Mankoo Lee ${ }^{* * * *}$ \\ Department of Health Care, Hanseo University, \\ Department of Diagnostic Radiology, Hallym University Hospitai** \\ Department of Radiological Science, Seonam University ${ }^{* * *}$ \\ Dept. of Radiologic Technology Wonkwang Health Science University ${ }^{* * * *}$
}

\section{진단용 $\mathrm{X}$ 선 발생장치의 성능 측정}

\author{
유인규,**, 임청환*, 이상호***, 이만구**** \\ 한서대학교 보건의료학과*, 한림대학교병원 영상의학과 ${ }^{* *}$, 서남대학교 방사선학과 ${ }^{* * *}$, 원광보건대학교 방사선과****
}

\begin{abstract}
To examine the performance of a diagnostic X-ray system, we tested a linearity, reproducibility, and Half Value Layer(HVL). The linearity was examined 4 times of irradiation with a given condition, and we recorded a level of radiation. We then calculated the $\mathrm{mR} / \mathrm{mAs}$. And the measured value should not be more than 0.1 . If the measured value was more than 0.1 , we could know that the linearity was decreased. The reproducibility was analyzed 10 times of irradiations at $80 \mathrm{kVp}, 200 \mathrm{~mA}, 20 \mathrm{mAs}$ and $120 \mathrm{kVp}, 300 \mathrm{~mA}, 8 \mathrm{mAs}$. The values from these analyses were integrated into $\mathrm{CV}$ equation, and we could get outputs. The reproducibility was good if the output was lower than 0.05. HVL was measured 3 times of irradiation without a filter, and we inserted additional HLV filters with 0,1, 2, $4 \mathrm{~mm}$ of thickness. We tested the values until we get the measured value less than a half of the value measured without additional filter. We tested the linearity, the reproducibility, and HVL of 5 diagnostic X-ray generators in this facilities. The linearity of No. 1 and No. 5 generator didn't satisfy the standard for radiation safety around $300 \mathrm{~mA} \sim 400 \mathrm{~mA}$ and $100 \mathrm{~mA} \sim 200 \mathrm{~mA}$, respectively. HVL of No.1 generator was not satisfied at $80 \mathrm{kVp}$. The outputs were higher in the three-phase equipment than the single-phase equipment. The old generators need to maintain and exchange of components based on the these results. Then, we could contribute to getting more exact diagnosis increasing a quality of the image and decreasing an expose dose of radiation.
\end{abstract}

Key Words : Linearity, Reproducibility, HVL

\section{요야}

본 연구는 진단용 X선 발생장치의 성능을 검사하기 위해 직선성(Linearity), 재현성(reproducibility) 및 반가층 (Half Value Layer; HVL)을 실험하였다. 직선성(Linearity)은 설정된 조사조건으로 한 장비 당 4 회씩 조사하여 측정 된 선량을 기록하고 $\mathrm{mR} / \mathrm{mAs}$ 를 구하여 측정하였으며, 측정값이 0.1 을 초과하면 직선성이 떨어지는 것을 알 수 있다. 재현성(Reproducibility)은 $80 \mathrm{kVp}, 200 \mathrm{~mA}, 20 \mathrm{mAs}$ 와 $120 \mathrm{kVp}, 300 \mathrm{~mA}, 8 \mathrm{mAs}$ 의 조건으로 10 회 조사하여 변동계수 
(CV) 공식에 대입하여 측정한 값이 0.05안에 포함되면 양호하게 나타나는 것을 알 수 있다. 반가층(Half Value Layer: $\mathrm{HVL}$ )은 filter가 없을 때 설정된 조건으로 3회 조사하여 측정한 후 부가필터용 반가층 물질로 사용하여 필터의 두께를 $0,1,2,4 \mathrm{~mm}$ 로 바꾸어 가며 부가필터가 없을 때의 $\frac{1}{2}$ 이하인 측정값이 나올 때 까지 측정한다. 현재 본원에서 사용하 는 진단용 $\mathrm{X}$ 선 발생장치 5 대를 대상으로 직선성, 재현성, 반가층을 측정한 결과 직선성은 1 번 장비에서는 $300 \mathrm{~mA} \sim 400 \mathrm{~mA}, 5$ 번 장비에서는 $100 \mathrm{~mA} 200 \mathrm{~mA}$ 부근에서 양호하지 않았으며, 반가층 측정에서는 $80 \mathrm{kVp}$ 측정치에 서 1 번 장비에서 검사기준을 만족하지 못하였다. 출력은 단상에 비해 삼상장치가 높게 나왔다. 실험을 통하여 밝혀진 결과를 토대로 정기적인 장비관리와 노후 된 장비의 교환 등이 이루어진다면 장비 사용의 효율성을 극대화 할 수 있으 며, 방사선 피폭선량을 줄임과 동시에 영상의 화질을 향상시킬 수 있어 정확한 진단에 기여할 수 있을 것으로 사료된 다.

중심단어: 직선성, 재현성, 반가층

\section{I. 서론}

최근 의과학의 발달과 함께 의료산업의 발전에 힘 입어 각종 의료기기를 이용한 질병의 진단기술이 급 속히 발전하고 있을 뿐만 아니라 그 사용 범위와 빈 도가 증가하고 있는 추세이다 ${ }^{[1]}$. 그 중에서도 진단용 $\mathrm{X}$ 선 발생장치는 질병의 초기 및 최종진단의 목적으로 그 활용도가 꾸준히 증가하고 있다. X선의 투과력은 인체 내부의 모든 구조와 국부적인 관찰을 위한 의료 분야에서 진단용 방사선 의료기기의 핵심이 되었으며, $\mathrm{X}$ 선을 인체에 조사하여 사진을 촬영하고, 그 내부 구 조의 상태를 알 수 있게 된 이래, 임상적 응용의 발전 에 중요한 기여를 하게 되었다 ${ }^{[2]}$.

1925년경에는 열전자 X선과 변압기식 고전압 발생 장치가 개발되어 대부분의 X선 발생장치는 상용교류 전원을 이용하여 교류고압을 발생시키고, 이 교류를 정류한 직류 고전압을 $\mathrm{X}$ 선관에 인가하여 $\mathrm{X}$ 선을 발생 시키는 정류관형 변압기식 고압발생장치가 주로 사용 되어 왔다 ${ }^{[3]}$. 이후 원리적으로 소형, 경량화가 어렵고 관전압의 맥동률이 커서 X선 발생효율이 매우 낮고 출력제어 장치의 동작이 정밀하지 못해 신뢰성이 문 제점으로 지적되어 이를 개선하기 위한 연구가 진행 되어 오던 중 새로운 전력변환과 제어장치 부분에 있 어서 고속 스위칭능력을 갖는 전력용 반도체스위칭 소자를 이용한 인버터식 $\mathrm{X}$ 선 발생용 장치가 개발이 되었고 진단용 X선장치에 인버터기술을 이용하여 1983년에 Toshiba사에서 처음으로 개발하여 1985년 이
후 인버터식 X선 장치가 실용화된 후 현재는 인버터 방식이 진단용X선 장비의 대부분을 차지하고 있다. 인 버터 방식은 진단 방사선 영역에서 요구하는 최소의 방사선 피폭으로 최상의 화상정보를 얻을 수 있고, 장 치의 소형, 경량화 할 수 있으며 높은 X선 출력에도 불구하고 정확한 제어가 가능하기 때문이다 ${ }^{[4]}$.

진단용 X선 발생기기는 인체 각 부위의 X선 투과 와 촬영 시 최소한의 피폭량으로 정확한 진단을 하기 위한 순시 대전력 발생기와 고밀도 에너지, 고내구성, 재현성 및 정밀한 제어성 등의 조건이 요구된다. 그러 나 의료기관에 설치되어 사용되고 있는 동일한 인버 터식 X선 장치라도 설치 조건과 사용 년수 등에 따라 서 출력과 선명도의 차이가 있고, $\mathrm{X}$ 선상의 화질과 환 자의 피폭선량이 다르다고 할 수 있다 ${ }^{[5]}$.

의료기관에서 사용 중인 진단용 X선 장치는 정류방 식의 차이에 따라 기기의 출력과 정확도등 여러 가지 요소에 의하여 촬영의 결과가 다르게 나타나, 정확한 장치의 사용과 알맞은 촬영조건의 선택이 중요하다. 최 근에는 영상전송장치(Picture Archiving and Communications System; PACS)가 의료기관에 많이 보급 이 되어 영상획득에 $\mathrm{CR}$ (Computed Radiography), DR(Digital Radiography) 장비를 선택하여 사용하고 있다.

본 연구의 목적은 진단용 방사선 발생장치의 정기 검사를 통과한 $\mathrm{CR}$ 과 $\mathrm{DR}$ 인버터식 $\mathrm{X}$ 선 발생장치를 정 류방식에 따라 분류하여 진단의 화질을 좌우하는 X선 장치의 출력과 선질을 평가하고자 한다. 주요 평가방 법은 장시간 사용 시에도 연속적으로 그 특성이 재현 
될 수 있어야 하는 재현성(Reproducibility), 화질 구현에 중요한 평가 요소인 관전류와 조사시간이 변화되어도 $\mathrm{mAs}$ 가 일정하면 $\mathrm{X}$ 선량은 항상 일정 출력량을 나타내 는 직선성(Linearity), 불균등한 연속스펙트럼을 갖고 있 는 $\mathrm{X}$ 선의 여과능력을 측정하여 선질을 평가하는 반가 층(Half Value Layer)을 이용하였다.

\section{II. 실험 대상 및 방법}

\section{1. 실험기기}

최고 관전압이 $150 \mathrm{kVp}$ 인 진단용 $\mathrm{X}$ 선발생장치 $\mathrm{CR}$, $\mathrm{DR}$ 장비 총 5 대를 가지고 재현성(Reproducibility), 직 선성(Liearity), 반가층 $(\mathrm{HVL})$ 을 측정하였다. 진단용 $\mathrm{X}$ 선 발생장치의 재원은 다음과 같다.

-1-Room (KXO-15R)

Power Supply Requirements : Single-Phase

Line Frequency : $50 / 60 \mathrm{~Hz}$

Inherent Filtration : $1.5 \mathrm{mmAl}$

Addition Filtration : $2.0 \mathrm{mmAl}$

\section{- 2. 3-Room(EPEX SYMPHONY/OMNIFLEX)}

Power Supply Requirements : Three-Phase

Line Frequency : $60 \mathrm{~Hz}$

Inherent Filtration : $1.5 \mathrm{mmAl}$

Addition Filtration : $2.0 \mathrm{mmAl}$

- 5-Room(KXO-50G)

Power Supply Requirements : Single- Phase

Line Frequency : 50/60Hz

Inherent Filtration : $0.5 \mathrm{mmAl}$

Addition Filtration : $1.2 \mathrm{mmAl}$

- 9-Room(UD150L-RII)

Power Supply Requirements : Three-Phase

Line Frequency : 50/60Hz

Inherent Filtration : $1.0 \mathrm{mmAl}$

Addition Filtration : $1.0 \mathrm{mmAl}$
출력 검출기로는 검 - 교정을 마친 Ion Chamber (Model 20X6-60E Electrometer)를 이용하여 측정하였다 (Fig. 1).

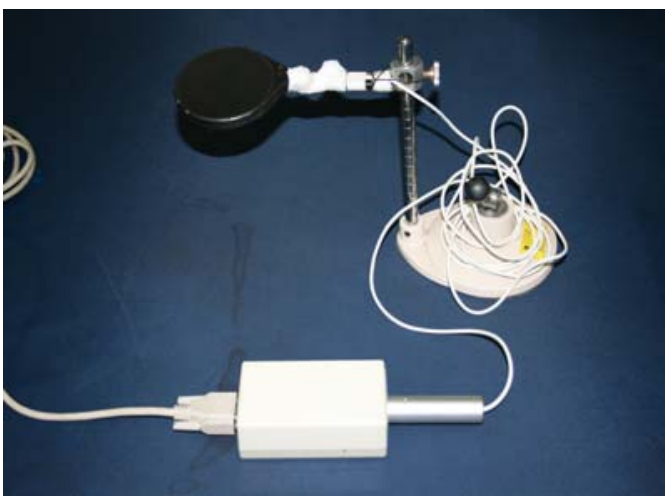

Fig. 1. Ion Chamber

\section{2. 실험방법}

\section{1) 출력의 재현성(Reproducibility)}

관전압 $(\mathrm{kVp})$, 관전류 $(\mathrm{mA})$, 조사시간 $(\mathrm{sec})$, 촬영거리 등 일정한 발생조건에서 조사하였을 때 항상 일정한 출력선량이 나오는가를 알아보는 것을 의미하는 것으 로 $\mathrm{X}$ 선 출력이 동일조건을 반복 사용할 때 어느 정도 안정되어 있는가를 평가하는 기준이 된다. 다양한 임 상촬영조건 중에서 재차 동일 조건이 설정되었을 때 먼저 출력과 그 다음의 출력이 어느 정도 일치하는가 를 변동계수(Coefficient of Varian: CV)로 나타낸다. 실 험방법은 $\mathrm{X}$ 선관 초점과 검출기간 거리를 $100 \mathrm{~cm}$ 으로 하고, 조사야를 $20 \times 20 \mathrm{~cm}$ 로 조정한 후 $80 \mathrm{kVp}, 200 \mathrm{~mA}$, $20 \mathrm{mAs}$ 와 $120 \mathrm{kVp}, 300 \mathrm{~mA}, 8 \mathrm{mAs}$ 조건으로 각각 10 회 측 정하였다. 출력의 재현성의 관한 진단용 발생장치의 검사기준에서는 조사선량에 대해서 변동계수는 0.05 이 하로 설정하며, 변동계수는 측정한 조사선량의 평균치 에 대한 표준편차로 변동계수는 식(1)과 같다.

$$
C V=\frac{S}{X} \leq 0.05
$$


$S:$ 조사선량 측정치 모집단에 대한 표준편차

$X$ : 측정치의 평균치

$X_{i}: i$ 번째의 조사선량측정치

$n$ : 측정회수

\section{2) 출력의 직선성(Linearity)}

관전압 $(\mathrm{kVp})$ 과 $\mathrm{mAs}$ 를 일정하게 하고 관전류 $(\mathrm{mA})$ 와 조사시간 $(\mathrm{sec})$ 을 변경시켜 발생되는 선량을 측정하고, 그 각각의 조건에서 일정한 선량이 나오는가를 알아 보는 것을 의미한다. 따라서 관전류와 조사시간이 변 화되어도 $\mathrm{mAs}$ 가 일정하면 $\mathrm{X}$ 선량은 항상 일정하여야 한다. 실험방법은 $\mathrm{X}$ 선관 초점과 검출기간 거리를 $100 \mathrm{~cm}$ 로 하고 조사야를 $20 \times 20 \mathrm{~cm}$ 로 한 후 $80 \mathrm{kVp}$ 에서 $\mathrm{mAs}$ 의 설정은 가장 일반적으로 사용하고 있는 $\mathrm{mAs}$ 를 기준으로 해서 조사시간을 선택한다. 본 실험에서는 $20 \mathrm{mAs}$ 에서 $100 \mathrm{~mA}, 200 \mathrm{~mA}, 320 \mathrm{~mA}, 400 \mathrm{~mA}$ 로 변경하면 서 각각 4 회 측정하였다. 출력의 직선성의 대한 변동 계수는 식(2)와 같다.

$$
\frac{X_{1}-X_{2}}{X_{1}+X_{2}} \leq 0.1
$$

여기서 $X_{1}, X_{2}$ 은 각각 최고치의 평균 $/ \mathrm{mAs}$ 와 최저 치의 평균 $/ \mathrm{mAs}$ 이고, 변동계수는 조사선량인 경우 0.1 이하가 되어야 한다.

\section{3) 반가층(Half Value Layer) 측정}

반가층이란 흡수체 투과 후의 강도가 투과 전의 강 도의 반이 되는 흡수체의 두께를 말한다. 즉 우리가 사용하는 불균등 $\mathrm{X}$ 선에 대한 선질 평가에 이용되고 있다. $\mathrm{X}$ 선관 장치의 초점에서 발생하는 $\mathrm{X}$ 선은 불균등 한 연속스펙트럼을 갖고 있다. 이 중 에너지가 낮고 파장이 긴 광자들은 대부분 피사체에 흡수되어 방사 선 피폭량을 증가시키는 요인이 되고 있다. 이 광자를 여과하기 위하여 $\mathrm{X}$ 선이 발생되어 나오는 창에 여과 판이 부착되어 있는데 이 여과판의 여과능력을 측정 하는 것이 매우 중요하다. 실험방법은 $\mathrm{X}$ 선관 초점과 검출기간 거리를 $100 \mathrm{~cm}$ 로 하고 조사야를 $20 \times 20 \mathrm{~cm}$ 로 한 후 filter가 없을 때 조사선량을 3회 측정한 후 부가
필터용 $\mathrm{Al}$ 을 반가층 측정 물질로 이용한다. 반가층 측 정용 물질을 $0,1,2,4 \mathrm{~mm}$ 로 바꾸어 가며 부가필터가 없을 때의 $1 / 2$ 이하가 될 때 까지 측정한다(Fig. 2).

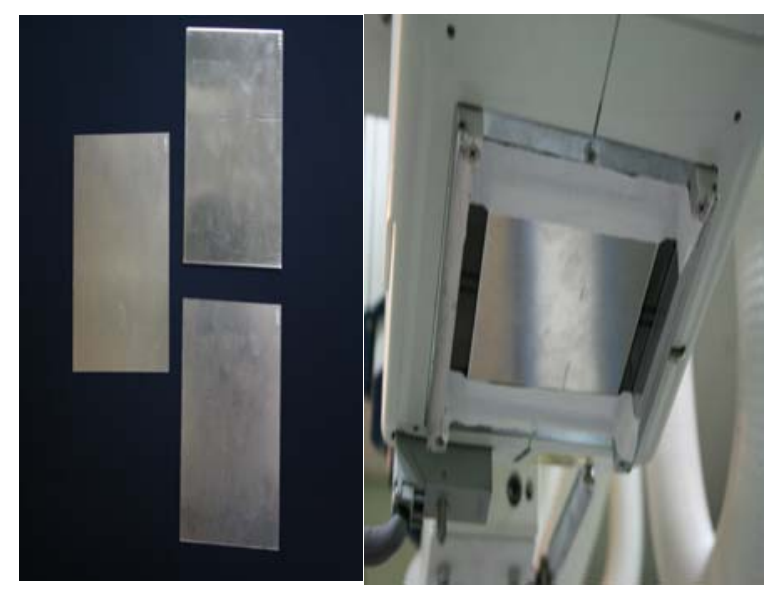

Fig. 2. HVL test

선질 측정을 위한 반가층 공식은 식(3)과 같다.

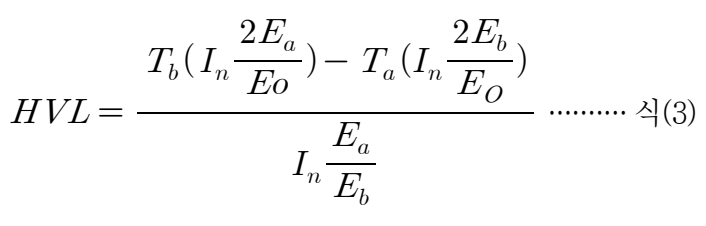

$E_{O}: \mathrm{Al}$ 흡수판이 없는 경우의 선량

$E_{a}: E_{o}$ 의 $\frac{1}{2}$ 보다 약간 큰 선량

$E_{b}: E_{o}$ 의 $\frac{1}{2}$ 보다 약간 작은 선량

$T_{a}: E_{a}$ 일 때의 $\mathrm{Al}$ 의 두께

$T_{b}: E_{b}$ 일 때의 $\mathrm{Al}$ 의 두께

진단용 $\mathrm{X}$ 선 장치 및 발생장치에 대한 반가층 시험 은 장치의 조사조건에 따라 시험했을 때 기준 관전압 에 따른 최소 반가층 이상이어야 한다. $60 \mathrm{kVp}$ 에서는 $\mathrm{Al}$ 의 최소값이 $1.3 \mathrm{~mm}$ 이상, $80 \mathrm{kVp}$ 에서는 $\mathrm{Al}$ 의 최소값 이 $2.3 \mathrm{~mm}$ 이상, $100 \mathrm{kVp}$ 에서는 $\mathrm{Al}$ 의 최소값이 $2.7 \mathrm{~mm}$ 이 상을 기준으로 하고 있으나 일반적으로 $80 \mathrm{kVp}$ 에서 $\mathrm{Al}$ 의 최소값인 $2.3 \mathrm{~mm}$ 이상을 기준으로 하고 있다. 
"Journal of the Korean Society of Radiology, Volume 6, Number 6"

\section{III. 실험결과}

\section{1. 출력의 재현성(Reproducibility) 결과}

재현성 측정결과 모든 진단용 장치에서 동일한 조 건에서 출력의 변동계수 $(\mathrm{CV})$ 가 0.05 이하에 포함되어 양호하게 나타났다(Table 1).

Table 1. Reproducibility

\begin{tabular}{ccccccccc}
\hline $\begin{array}{c}\text { Equip } \\
\text { ment }\end{array}$ & KV & mA & mAs & Mean(mR) & SD & CV & $\begin{array}{c}\text { Evalua } \\
\text { t ion }\end{array}$ \\
\hline $\begin{array}{c}\text { No. 1 } \\
\text { (Single } \\
\text { phase) }\end{array}$ & 120 & 200 & 20 & 100.3 & 0.357 & 0.0035 & 0 \\
\hline $\begin{array}{c}\text { No. 2 } \\
\text { (Three } \\
\text { phase) }\end{array}$ & 120 & 300 & 8 & 200 & 154.2 & 0.097 & 0.0005 & 0 \\
\hline $\begin{array}{c}\text { No. 3 } \\
\text { (Three } \\
\text { phase) }\end{array}$ & 120 & 200 & 20 & 132.9 & 0.184 & 0.0013 & 0 \\
\hline $\begin{array}{c}\text { No. 5 } \\
\text { (Single } \\
\text { phase) }\end{array}$ & 80 & 200 & 20 & 85.14 & 0.151 & 0.0017 & 0 \\
\hline $\begin{array}{c}\text { No. 9 } \\
\text { (Single } \\
\text { phase) }\end{array}$ & 120 & 300 & 800 & 20 & 107.3 & 0.151 & 0.0014 & 0 \\
\hline
\end{tabular}

변동계수가 0.0005 0.007 범위 내에 있으므로 본 실 험에 사용된 모든 진단용 장비에 대한 출력의 재현성 은 성능관리가 잘 되고 있었으며, 동일한 조건하에서 는 2,3 번 장비 즉 3 상장비가 재현성이 상대적으로 1 , 5,9 번 단상장비에 비하여 우수하였으며, 동일한 조건 하에서 출력을 보면 상대적으로 3상장비인 2, 3번 장 비가 단상장비에 비해 평균 $30 \%$ 이상 양호하게 평가되 었다.

\section{2. 출력의 직선성(Linearity) 결과}

직선성 측정결과 전체적으로는 직선성이 양호하게 측정이 되었으나 1 번 단상장비에서는 $320 \sim 400 \mathrm{~mA}, 5$ 번 단상장비에서는 $100 \sim 200 \mathrm{~mA}$ 에서 출력의 직선성이 변동 계수 0.1 을 넘어 양호하지 않게 측정되었다(Table 1).
Table 2. Linearity

\begin{tabular}{|c|c|c|c|c|c|c|c|}
\hline $\begin{array}{c}\text { Equip } \\
\text { ment }\end{array}$ & $\mathrm{KV}$ & $\mathrm{mA}$ & mAs & Mean (mR) & $\mathrm{mR} / \mathrm{mAs}$ & Linear ity & $\begin{array}{c}\text { Evalua } \\
\text { tion }\end{array}$ \\
\hline \multirow{4}{*}{$\begin{array}{l}\text { No. } 1 \\
\text { (Single } \\
\text { phase) }\end{array}$} & 80 & 100 & 20 & 94.725 & 4.736 & & \\
\hline & 80 & 200 & 20 & 100.725 & 5.0362 & 0.03 & 0 \\
\hline & 80 & 320 & 20 & 87.625 & 4.381 & 0.069 & 0 \\
\hline & 80 & 400 & 20 & 63.625 & 3.181 & 0.15 & $x$ \\
\hline \multirow{4}{*}{$\begin{array}{l}\text { No. } 2 \\
\text { (Three } \\
\text { phase) }\end{array}$} & 80 & 100 & 20 & 147.7 & 7.385 & & \\
\hline & 80 & 200 & २० & 153.8 & 7.69 & 0.02 & 0 \\
\hline & 80 & 320 & 20 & 153.4 & 7.67 & 0.019 & 0 \\
\hline & 80 & 400 & 20 & 151.1 & 7.555 & 0.01 & 0 \\
\hline \multirow{4}{*}{$\begin{array}{l}\text { No. } 3 \\
\text { (Three } \\
\text { phase) }\end{array}$} & 80 & 100 & 20 & 131.375 & 6.568 & & \\
\hline & 80 & 200 & 20 & 133.375 & 6.668 & 0.007 & 0 \\
\hline & 80 & 320 & 20 & 133.875 & 6.693 & 0.001 & 0 \\
\hline & 80 & 400 & 20 & 133.075 & 6.653 & 0.002 & 0 \\
\hline \multirow{4}{*}{$\begin{array}{l}\text { No. } 5 \\
\text { (Single } \\
\text { phase) }\end{array}$} & 80 & 100 & 20 & 56.375 & 2.818 & & \\
\hline & 80 & 200 & 20 & 85 & 4.25 & 0.202 & $x$ \\
\hline & 80 & 350 & 20 & 109.775 & 5.488 & 0.001 & 0 \\
\hline & 80 & 400 & 20 & 109.425 & 5.471 & 0.038 & 0 \\
\hline \multirow{4}{*}{$\begin{array}{l}\text { No. } 9 \\
\text { (Single } \\
\text { phase) }\end{array}$} & 80 & 100 & 20 & 118.075 & 5.903 & & \\
\hline & 80 & 200 & 20 & 121.175 & 6.058 & 0.012 & 0 \\
\hline & 80 & 320 & 20 & 121.875 & 6.093 & 0.002 & 0 \\
\hline & 80 & 400 & 20 & 117.35 & 5.867 & 0.018 & 0 \\
\hline
\end{tabular}

변동계수를 보면 기준치 0.1 이하로 볼 때 3 상 장비 인 5 번 장치가 가장 양호하게 평가되었다.

\section{3. 반가층(Half Value Layer) 측정결과}

$\mathrm{X}$ 선의 강도를 반으로 줄이는데 필요한 흡수체의 두 께를 구하는 반가층 측정결과 $80 \mathrm{kVp}$ 에서 반가층이 $2.3 \mathrm{mmAl}$ 이상을 권고 사항으로 하였을 때 단상 1 번 장비를 제외한 모든 진단용 $\mathrm{X}$ 선 장비에서는 양호하게 측정이 되었다(Table 3$)$. 
Table 3. HVL

\begin{tabular}{llllllll}
\hline $\begin{array}{c}\text { Equip } \\
\text { ment }\end{array}$ & $E_{O}$ & $E_{a}$ & $E_{b}$ & $T_{a}$ & $T_{b}$ & $H V L$ & $\begin{array}{c}\text { Evalua } \\
\text { tion }\end{array}$ \\
\hline $\begin{array}{c}\text { No. 1 } \\
\text { (Single } \\
\text { phase) }\end{array}$ & 102.1 & 52.9 & 39.3 & 2 & 3 & 2.1197 & $\times$ \\
\hline $\begin{array}{l}\text { No. 2 } \\
\text { (Three } \\
\text { phase) }\end{array}$ & 240.2 & 145.2 & 119.5 & 2 & 3 & 2.9742 & 0 \\
\hline $\begin{array}{l}\text { No. 3 } \\
\text { (Three } \\
\text { phase) }\end{array}$ & 214.2 & 130.6 & 107.5 & 2 & 3 & 3.0191 & 0 \\
\hline $\begin{array}{l}\text { No. 5 } \\
\text { (Single } \\
\text { phase) }\end{array}$ & 172.2 & 99 & 85 & 3 & 4 & 3.9156 & 0 \\
\hline $\begin{array}{l}\text { No. 9 } \\
\text { (Single } \\
\text { phase) }\end{array}$ & 178.2 & 93.6 & 78.9 & 3 & 4 & 3.2719 & 0 \\
\hline
\end{tabular}

\section{IV. 고찰}

진단용 X선장비의 출력의 재현성(Reproducibility)을 정류방식에 따라 구분하여 측정한 결과 변동계수는 설 정치 안에 포함되어 양호하게 평가되었으나, 출력의 변동계수를 보면 3상장비는 촬영조건에 변화에도 큰 변화가 없으나 단상장비는 촬영조건의 따라 변화폭이 3상장비에 비해 상대적으로 차이가 있었다. 이는 관전 압의 차이에 따른 맥동률이 X선 출력선량에 영향을 주 어 상대적으로 3 상장비의 출력이 양호했기 때문이다 ${ }^{[6]}$.

출력의 직선성(Linearity)은 미국의 FDA의 규정에 의 하면 "이웃하는 관전류 조정단계 사이에 $\mathrm{mAs}$ 에 대한 선량이 $\pm 10 \%$ (직선성: 0.1 )이내에 일치하여야 한다"로 규정되어 있고, 진단용 $\mathrm{X}$ 선 발생장치의 검사항목에는 직선성에 대한 검사는 포함되어 있지 않으나, 한국공 업규격(KS)에는 출력의 직선성을 이웃하는 설정치에 서의 직선성으로 나누어 규정하고 있다 ${ }^{[7]}$.

반가층 $(\mathrm{HVL})$ 측정은 한국공업규격 $(\mathrm{KS})$ 이나 일본공 업규격(JIS) 및 미국보건성(USA-Department of Health: Education and Welfare)에 의하면 X선 장치의 정격 관 전압에 따라 총 여과를 공통적으로 정하고 있다 ${ }^{[8]}$.

방사선 진단 시 이용되고 있는 장치에 대한 설치 및 이용규정에 있어서는 국제기구나 단체에서 품질 및
성능관리프로그램을 개발, 권고를 하고 있다. 이에 따 라 국내에서는 보건복지부고시로서 시험기준이나 시 험방법을 제한해 오다가 식품의약품안전청이 1995년 제정한 “진단용 방사선 발생장치의 안전관리에 관한 규칙”이 공포되어 사전 품질관리와 사후 성능관리가 이루어지게 되었다 ${ }^{[9]}$. 현재는 진단용 발생장치에서 특 수의료 장비까지 확대되어 안전관리를 시행하고 있다. 병원에서 사용되는 진단용 $\mathrm{X}$ 선 장비는 3 년마다 안전 관리에 관한 규정에 의해 정기검사가 실시되고 있으 며, 검사기준을 충족하지 못한 장비는 사용을 금지하 고 있다 ${ }^{[10[11]][12]}$. 따라서 국내에서는 보건복지부령 방 사선발생장치의 안전관리에 관한 규칙에 의거하여 장 치의 성능관리를 하여야 한다. 하지만 현재 대부분의 의료시설에서는 방사선 안전관리의 의한 정기적인 성 능검사를 대행업체에 일임하여 실시하고 있으며 형식 적인 면에 치우치고 있는 실정이다. 경기도 소재한 본 대학병원에서 조차 방사선 안전관리의 의한 정기적인 성능검사를 통과한 진단용 $\mathrm{X}$ 선 발생기에서도 출력의 재현성은 모두 양호하게 나타났으나, 출력의 직선성이 나 반가층 측정에서 단상장비는 부적합하였다. 수도권 지역의 일반촬영 장비 정도관리 분석에서는 개인병원 및 교육기관과와 일부 종합병원에서도 진단용 $\mathrm{X}$ 선 발 생장치의 성능검사 결과가 부적합하였다 ${ }^{[13]}$. 이러한 장 치의 성능저하가 영상진단에 있어 부적절한 화질을 발생시키고 이는 재촬영률을 높여 피폭량의 증가와 더불어 업무의 효율성을 떨어트리는 결과를 초래할 수 있다 ${ }^{[14]}$. 장비의 성능과 관련된 다른 선행연구에서 도 소형병원일수록 장비의 성능은 떨어진다고 보고하 고 있으며, 노후화된 장비일수록 성능 검사를 자주 해 야 하며, 제조 회사가 지정하는 기간 안에 전반적인 점검을 실시할 것을 권고하고 있다다. 본원의 출력의 직선성 측정결과 양호하게 나타나지 않는 장비가 발 생하였는데 이는 X선 장비의 노후에 따른 결과물로 보여지나 추후 정확한 검사가 요구된다.

반가층은 $\mathrm{X}$ 선관에서 발생되는 $\mathrm{X}$ 선이 불균등하기 때문에 이를 평가하는 요소로 사용되고 있다. 에너지 가 낮은 X선은 영상에는 관여하지 못하고 환자의 피 폭만 증가하게 되므로 필터를 통해 저에너지 $\mathrm{X}$ 선을 제거해야 하는데 이 선질을 시험하기 위한 방법으로 반가층시험법이 이용되고 있다. 따라서 선질을 규제하 
"Journal of the Korean Society of Radiology, Volume 6, Number 6"

는 국가적 기준에 따라 우리나라에서도 최소 반가층 이 규정되어 있는 것이다 ${ }^{[16]}$. 진단용 $\mathrm{X}$ 선 장치에서는 제작단계에서 규정된 선질이 발생할 수 있도록 해야 하며 임상에서 사용할 때는 선질관리를 통해 피폭선 량의 감소와 화질관리가 잘 이루어지도록 할 필요가 있다. 이러한 선질 평가항목인 반가층 시험은 진단용 발생장치의 안전관리규칙 보건복지부령 제 349 호에 의 해 2006년에 개정되어 시행되고 있다.

병원에서 사용되는 진단용 X선 장치가 3 년마다 안 전관리 규정에 의해 정기검사가 실시됨에도 불구하고 ${ }^{[17]}$ 기준치가 벗어난다면 정확도가 높은 측정기를 바 탕으로 한 측정기기 업체를 선정해서 성능관리를 시 행하고 검사주기도 정기검사 외에 방사선관계종사자 들이 자체적으로 기간을 단축하여 진단용 발생장치의 성능을 일정하게 유지하고, 노후된 장비를 교체하여 의료영상 질 관리 수준을 향상시켜 환자에게 정확한 의료정보를 제공할 수 있는 여건을 마련해야 한다. 더 불어 우리나라 어느 일부지역 X선 발생장치의 정도관 리에 관한 현황조사를 보면 현재 근무하고 있는 병원 에서 정도관리에 관한 교육을 받은 적이 있느냐는 질 문에 조사한 50명 모두 '한 번도 없다라고 보고하고 있다 ${ }^{[18]}$ 진단방사선 발생장치를 다루는 담당자의 의식 전환이 반드시 필요하며 정도관리의 중요성에 대한 인식을 높이는 노력이 필요하다고 사료된다.

\section{$\mathrm{V}$. 결론}

진단용 방사선 발생장치의 정기검사를 통과한 $\mathrm{CR}$ 과 $\mathrm{DR}$ 인버터식 $\mathrm{X}$ 선 발생장치 5 대를 정류방식에 따 라 분류하여 진단의 화질을 좌우하는 $\mathrm{X}$ 선 장치의 출 력과 선질을 평가하였다.

출력의 재현성(Reproducibility) 측정결과 모든 진단 용 장치에서 동일한 조건에서 출력의 변동계수 $(\mathrm{CV})$ 가 0.05 안에 포함되어 양호하게 나타났다.

출력의 직선성(Linearity) 측정결과 전체적으로 직선 성이 양호하게 측정이 되었으나 1 번 단상장비에서는 $320 \sim 400 \mathrm{~mA}$ 에서, 5 번 단상장비에서는 $100 \sim 200 \mathrm{~mA}$ 에서 출력의 직선성이 변동계수 0.1 을 넘어 양호하지 않게 측정이 되었다.
선질을 측정하는 반가층 $(\mathrm{HVL})$ 측정결과 $80 \mathrm{kVp}$ 에 서 반가층이 $2.3 \mathrm{mmAl}$ 이상을 권고 사항으로 하였을 때 단상 1 번 장비를 제외한 모든 진단용 $\mathrm{X}$ 선 장비에 서는 양호하게 측정되었다.

이와 같은 결과로 방사선 발생장치의 안전 및 성능 관리의 심각성을 알 수 있었으며, 노후된 장비를 교체 하고 양호한 출력을 유지하기 위해 방사선 종사자의 자체적인 성능검사 및 체계적이고 주기적인 성능검사 와 그 검사결과에 따른 기술적, 행정적인 조치들이 이 루어 져야 한다.

\section{감사의글}

이 논문은 2011년도 원광보건대학교 교내 연구비 지원에 의해 연구되었습니다.

\section{참고문헌}

[1] Manny Roman, "Radiology maintenance-circle of quality assurance" Jounal of Clinical Engineering. pp.413 418, 1993.

[2] H. Hino, T. Hatakeyama, M. Nakaoka, "Resonant PWM inverter linked DC-DC converter using parasitic impendance of high-voltage tansforer and its applications to x-ray generator" PESC 188 Record 19th Annual IEEE, Power Electronics Specialists Conference. Vol. 66, No. 6, pp.969-983, 1989.

[3] H. S. Kim, C. Y. Won, D. W. Yoo, S. W. Ha, "A study on High Power Resonant Converter for X-ray Generator", Proceedings of ICPE95, PP. 288-294, 1995.

[4] 강영태. "High frequency방식 X선 장치의 특성" Image Research, Vol. 2, No. 3, pp.15 26, 1994.

[5] 윤종섭, 김춘식, 고신관, “의료용 $\mathrm{X}$ 선 장치의 유지 및 성능관리에 관한 검토”, 대한방사선기술학회지, 제 5 권, 제1호., pp.2-26, 1992.

[6] 황춘성, "X-선 발생장치의 출력특성에 관한 연구”, 조선대학교 산업대학원 전기공학과, 석사학위논문, pp.33-35, 1999.

[7] William M . Flanagan, Hand Book of Transformer Design and Applications, McGraw-Hill Inc, 1992.

[8] Daneil A. Gollnick, "Experimental Radiological Health Physics, Pergamon Press”, pp.135-140, 1978.

[9] 김정민, "진단용 엑스선장치의 주기적 성능관리 방안." 식품의약품안전청, 방사선 보건 Newletter, Vol. 19, No. 1, pp.15, 2012.

[10] 보건복지부령 제186호. 진단용 방사선 발생장치의 
안전관리의 관한 규칙. 2001.

[11] 보건복지부령 제234호. 진단용 방사선 발생장치의 안전관리의 관한 규칙. 2003.

[12] 보건복지부령 제 349 호. 진단용 방사선 발생장치의 안전관리의 관한 규칙. 2006.

[13] 강병삼 외, “수도권지역 일반촬영 장비의 정도관리 분석". 방사선기술과학회지, Vol. 35, No. 2, pp.93-101, 2012..

[14] 김병준, 박덕우, 정병훈. “일반 촬영 장비의 정도 관리 중요성을 위한 기준 평가 연구와 실태조사". 신구대학교 방사선기술과학, 제25호, pp. 109-116, 2010.

[15] 임인철, 박주훈, 동경래, “병원규모별 진단용X선 발생장치의 성능 평가", 방사선방어학회지, 제 34 권, 제 1 호, pp. 31-36, 2009.

[16] 강세식, “방사선기기 정도관리 및 실험”, 정문각, 2000.

[17] 보건복지부령 제 349 호. 진단용 방사선 발생장치의 안전관리의 관한 규칙(제 4 조 2 항). 검사 및 측정항목. 2006.

[18] 권대철, 동경래, 이선주, " 1 차 의료기관의 엑스선 발생장치 정도관리에 관한 현황조사”, 방사선방어학회지, 제 35 권, 제1호, pp. 34-42, 2010. 